\title{
Nitrogen regeneration in the NE Atlantic Ocean and its impact on seasonal new, regenerated and export production
}

\author{
Camila Fernández I. ${ }^{1,2, *}$, Patrick Raimbault ${ }^{1}$ \\ ${ }^{1}$ Laboratoire d'Océanographie et de Biogéochimie, Centre d'Océanologie de Marseille, 163 Av. de Luminy, Case 901, \\ PO Box 13288, Marseille, France \\ ${ }^{2}$ Present address: Laboratorio de Procesos Oceanográficos y Clima (PROFC), Departamento de Oceanografía, \\ Universidad de Concepción, Casilla 160-C, Concepción, Chile
}

\begin{abstract}
Nitrate and ammonium assimilation, nitrification and ammonium regeneration were measured during field experiments in the NE Atlantic ( 39 to $44.5^{\circ} \mathrm{N}, 16$ to $21^{\circ} \mathrm{W}$; Programme Océan Multidisciplinaire Méso Echelle) in 2001. $\mathrm{NH}_{4}{ }^{+}$and $\mathrm{NO}_{2}{ }^{-}$concentrations were high during winter and spring, reaching maximum values of 0.3 and $0.6 \mu \mathrm{M}$, respectively, in the top $100 \mathrm{~m} .{ }^{15} \mathrm{~N}$ tracer experiments allowed the measurement of nitrification throughout the water column, and rates in surface waters varied between $0.02 \mu \mathrm{M} \mathrm{d}^{-1}$ in winter and $0.077 \mu \mathrm{M} \mathrm{d}^{-1}$ in spring. At $30 \mathrm{~m} \mathrm{depth}$, rates could exceed $0.1 \mu \mathrm{M} \mathrm{d}^{-1}$ during the spring bloom. For the winter season, nitrification could account for $40 \%$ of the assimilated nitrate. During spring, nitrification could support more than $20 \%$ of nitrate assimilation. Ammonium regeneration was significant during both seasons, with average rates exceeding $0.5 \mu \mathrm{M} \mathrm{d}^{-1}$. Correction for $\mathrm{NH}_{4}{ }^{+}$isotopic dilution could increase estimations of regenerated production by $40 \%$. Also, a new evaluation of the $f$ ratio (including nitrification and ammonium isotopic dilution) showed a $10 \%$ overestimation of classic estimations of export production. Additionally, active $\mathrm{NH}_{4}{ }^{+}$uptake by $<0.7 \mu \mathrm{m}$ particles (mainly bacteria) was observed during late spring, suggesting that a significant fraction of small particles was not retained by GF/F filters during the spring bloom, which could lead to underestimations of $\mathrm{NH}_{4}{ }^{+}$uptake.
\end{abstract}

KEY WORDS: Nitrification · Ammonium regeneration · NE Atlantic

Resale or republication not permitted without written consent of the publisher

\section{INTRODUCTION}

New and regenerated production (Dugdale \& Goering 1967) are 2 important variables characterizing the efficiency of carbon and nitrogen cycling. Through the $f$ ratio (Eppley \& Peterson 1979), both variables combine to give an estimation of the fraction of biological production that can be potentially exported to the deep ocean. New production has long been defined as the fraction of primary production driven by the input of nutrients (mostly nitrate) into the euphotic zone, while regenerated production is fuelled by recycled nitrogen (mainly ammonium and dissolved organics) produced in situ by heterotrophic processes. However, in recent years, an accurate definition as well as a precise esti- mation of the efficiency of the biological pump has become of crucial importance when defining the role of oceanic areas in the sequestration of atmospheric $\mathrm{CO}_{2}$ (Takahashi et al. 2002).

Nitrification (the oxidation of $\mathrm{NH}_{4}{ }^{+}$to $\mathrm{NO}_{3}{ }^{-}$mediated by bacteria) is an important variable, not only considered responsible for the deep nitrate reservoir but also believed to provide a source of in situ regenerated nitrate at the base of the euphotic zone (where phytoplankton is light-limited to compete for $\mathrm{NH}_{4}{ }^{+}$; see review by Ward 2000). Nitrification in surface layers may also cause an overestimation of new production through autotrophic uptake of recycled nitrate in the euphotic zone (Ward 1987, Ward et al. 1989, Eppley \& Renger 1992, Gentilhomme \& Raimbault 1994, Dore \& 
Karl 1996, Raimbault et al. 1999, Diaz \& Raimbault 2000), but this has not been precisely quantified. Studies on $\mathrm{N}$ regeneration and release of dissolved organic nitrogen (DON) inspired several revisions of the concepts of new and regenerated production (e.g. Bronk et al. 1994). However, failure in estimating dissolved inorganic nitrogen (DIN) taken up by phytoplankton and released as DON represents another and yet unresolved source of error in DIN gross uptake rates (Bronk et al. 1994, Slawyk \& Raimbault 1995). Also, ammonium isotope dilution (recycling of unlabeled substrate during ${ }^{15} \mathrm{~N}$ incubation experiments) can result in underestimations of uptake rates (Glibert et al. 1982, Harrison et al. 1983). Nevertheless, the impact of these processes in new production models suffers from a general lack of data, probably related to schedule constraints and the labour intensive nature of the methods involved.

The French Programme Océan Multidisciplinaire Méso Echelle (POMME; Mémery et al. 2005) was conceived as a contribution to the understanding of the effect of mode water subduction on the production and fate of organic matter. The sampling strategy was designed to obtain high frequency coverage in core parameters in a vast domain set at 38 to $45^{\circ} \mathrm{N}, 16$ to $22^{\circ} \mathrm{W}$ (Fig. 1). Two consecutive cruises (winter and spring) in 2001 provided a unique chance to measure nitrogen cycling with high spatial resolution and to provide an accurate estimation of the proportion of nitrate resulting from nitrification that is assimilated within the euphotic zone in the eastern North Atlantic.

\section{MATERIALS AND METHODS}

Sampling and study area. Two consecutive cruises were carried out during winter and spring 2001 (RV 'L'Atalante'): POMME 1 (3 February to 20 March; Fig. 1) and POMME 2 (24 March to 16 May; Fig. 1). Core and biological parameters were acquired along 7 north-south transects (30 nautical mile path; see Mémery et al. 2005). The first leg of POMME 1 (P1L1) aimed to describe pre-bloom conditions and maximum mixed layer depth. From a total of 79 stations, 26 'production' stations were visited during the night (Fig. 1). At each production station, samples from 8 depths (5, $20,30,40,50,60,80$ and $100 \mathrm{~m}$ ) were collected using a rosette equipped with 21 Niskin bottles (11 l). Incubations lasted for $12 \mathrm{~h}$ (dawn to dusk) using deck incubators (light levels ranging from 50 to $1 \%$ of light). The first leg of POMME 2 (P2L1) followed an identical sampling strategy. From a total of 81 hydrological stations, 18 'production' stations were completed (Fig. 1).

During the second leg of both cruises (P1L2 and P2L2), several fixed stations were occupied for $72 \mathrm{~h}$ during which time ${ }^{15} \mathrm{~N}$ uptake and regeneration experiments were performed (Fig. 1). The choice of stations was determined by the hydrological features encountered (see Mémery et al. 2005). Incubations (using an in situ mooring line) lasted for $24 \mathrm{~h}$. Comparisons between 'on deck' and in situ incubation methods showed good linearity (Fernández I. et al. 2005a).

Mixed and euphotic layer depths. The euphotic layer depth $\left(Z_{\text {eu }}\right)$ was calculated using the model devel-

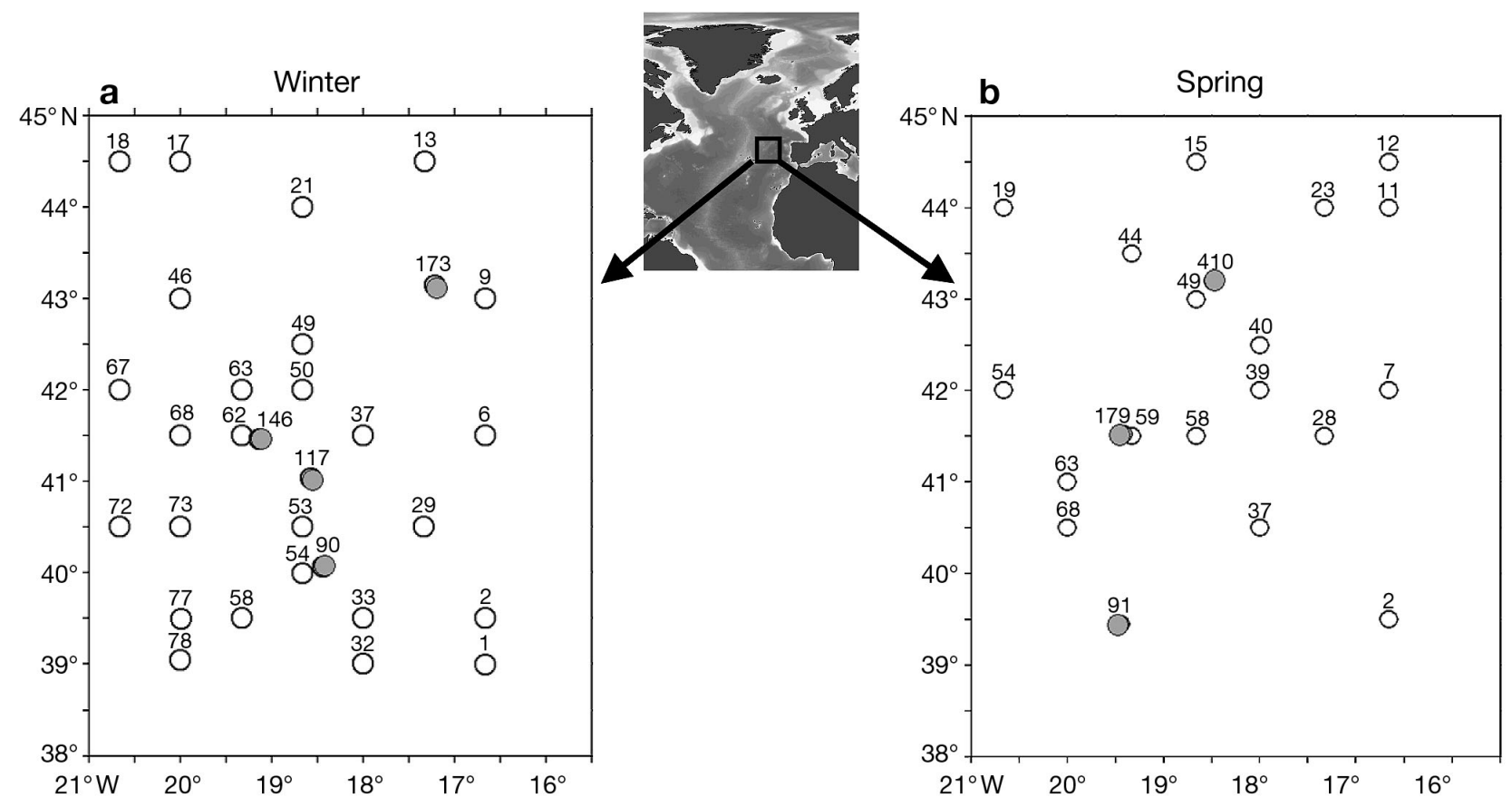

Fig. 1. Study area and sampling stations where ${ }^{15} \mathrm{~N}$ enrichment experiments were performed. (a) Winter. Open circles: P1L1; filled circles: P1L2. (b) Spring. Open circles: P2L1; filled circles: P2L2. Station numbers are indicated 
oped by Morel \& Maritorena (2001), according to which total chl a (Tchl a) content in the water column is obtained by integrating chl a over depth. The mixed layer depth $\left(Z_{\mathrm{m}}\right)$ is defined here as the depth level at which a change in potential density $(\sigma$ higher than $0.001 \mathrm{~kg} \mathrm{~m}^{-3}$ is observed in 2 consecutive determinations spaced by $5 \mathrm{~m}$ within a CTD cast (Fernández I. et al. 2005a,b).

Nutrients. Nutrient samples $\left(\mathrm{NO}_{3}^{-}, \mathrm{NO}_{2}{ }^{-}, \mathrm{PO}_{4}^{-}\right)$were collected at every station and at each depth level in $20 \mathrm{ml}$ polyethylene flasks. Samples for $\mathrm{NH}_{4}{ }^{+}$determination were collected between the surface and $200 \mathrm{~m}$ (250 ml Nalgene flasks) at approximately $50 \%$ of the stations. All samples were immediately analyzed (Tréguer \& Lecorre 1975) using a Technicon Autoanalyser. Detection limits (and analytical precision) were $0.05( \pm 0.04), 0.01( \pm 0.025), 0.015( \pm 0.01)$ and 0.01 $( \pm 0.01) \mu \mathrm{M}$ for $\mathrm{NO}_{3}{ }^{-}, \mathrm{NO}_{2}{ }^{-}, \mathrm{PO}_{4}{ }^{-}$and $\mathrm{NH}_{4}{ }^{+}$respectively.

Nitrogen-15 assimilation experiments. Rates of nitrate $\left(\rho \mathrm{NO}_{3}\right)$ and ammonium uptake $\left(\rho \mathrm{NH}_{4}\right)$ were measured using ${ }^{15} \mathrm{~N}$ stable isotopes. Samples $(600 \mathrm{ml})$ were collected before sunrise in acid-cleaned polycarbonate flasks. Ambient nitrate, nitrite and ammonium concentrations were immediately measured. Nitrogen-15 tracer additions as $\mathrm{K}^{15} \mathrm{NO}_{3}\left(99 \%\right.$ at $\left.0.5 \mu \mathrm{mol} \mathrm{ml} \mathrm{m}^{-1}\right)$ were always close to $10 \%$ of ambient concentrations. Nitrogen 15 tracer additions as ${ }^{15} \mathrm{NH}_{4} \mathrm{Cl}(99 \%$ at $0.5 \mu \mathrm{mol}$ $\mathrm{ml}^{-1}$ ) were more variable due to low initial $\mathrm{NH}_{4}{ }^{+}$concentrations (<50 nM). In such cases, minimal additions of ${ }^{15} \mathrm{~N}\left(87 \mathrm{nmol} \mathrm{l} \mathrm{l}^{-1}\right.$ of ${ }^{15} \mathrm{NH}_{4}$ ) resulted in substrate enrichments that exceeded $50 \%$, leading to potential productivity measures rather than real uptake (Allen et al. 1996, Raimbault et al. 1999, Fernández I. et al. 2005a). $\mathrm{NO}_{3}{ }^{-}$and $\mathrm{NH}_{4}{ }^{+}$concentrations were usually verified after tracer addition ( $t_{0}$ values). Incubations were terminated by filtration onto $25 \mathrm{~mm}$ pre-combusted GF/F filters (<100 mm Hg). Final concentrations of nitrate and ammonium were measured directly from the PC flask. Subsequent to filtration, filters were dried at $60^{\circ} \mathrm{C}$ and stored at $40^{\circ} \mathrm{C}$. Mass spectrometry analysis (Europa scientific tracer mass) determined the final ${ }^{15} \mathrm{~N}$ enrichment in the particulate organic nitrogen (PON) pool. The transport rate of ${ }^{15} \mathrm{~N}$-labelled DIN from the DIN pool to the PON pool, i.e. the net DIN uptake ( $\rho D I N, \mu \mathrm{M} \mathrm{d}^{-1}$ ) was computed according to Dugdale \& Wilkerson (1986)

$$
\rho \mathrm{DIN}=\frac{R_{\mathrm{PON}}}{R_{\mathrm{DIN}} \times t} \times[\mathrm{PON}]
$$

where $R_{\mathrm{PON}}$ and $R_{\mathrm{DIN}}$ represent the ${ }^{15} \mathrm{~N}$ atom percent excess enrichment in the PON and DIN pools, and $[\mathrm{PON}]$ represents the final PON concentration; $t$ (in all equations) represents the duration (h) of the incubation.

After filtration, $300 \mathrm{ml}$ filtrates were recovered in Duran Schott flasks. For samples obtained during the second leg of POMME 2, subsamples $(100 \mathrm{ml})$ were refiltered through teflon $0.2 \mu \mathrm{m}$ membranes (GELMAN and Anodisc Whatman). Filtrates were poisoned with $1 \mathrm{ml}$ (300 $\mu \mathrm{l}$ for $100 \mathrm{ml}$ subsamples) of $\mathrm{HgCl}_{2}\left(6 \mathrm{~g} \mathrm{l}^{-1}\right)$ in order to prevent bacterial activity during conservation. This procedure does not affect the extraction efficiency and prevents losses of $\mathrm{NH}_{4}{ }^{+}$by freezing the sample (Slawyk \& Raimbault 1995). Filtrates of ${ }^{15} \mathrm{NH}_{4}{ }^{+}$incubations were used to measure the final ${ }^{15} \mathrm{~N}$ enrichment in the DIN pool, as outlined by Slawyk \& Raimbault (1995). In this procedure, all forms of DIN are removed from the sample as $\left(\mathrm{NH}_{4}\right)_{2} \mathrm{SO}_{4}$, by successive diffusion and reduction processes. The first diffusion step allows quantification of the final ${ }^{15} \mathrm{~N}$ enrichment of the DIN pool $\left(\mathrm{DIN}^{15} \mathrm{~N}\right)$, and estimation of the isotope dilution of the tracer due to $\mathrm{NH}_{4}{ }^{+}$regeneration (see Eq. 2). During the second diffusion, oxidation of ammonium to nitrate (nitrification) is estimated through the ${ }^{15} \mathrm{~N}$ enrichment of the nitrate pool in the ammonium filtrates (Raimbault et al. 1999, Fernandez I. et al. 2005a). During the third diffusion, the fraction of ${ }^{15} \mathrm{DIN}$ absorbed by microorganisms and released as DON during the incubation was estimated ( $\rho_{\mathrm{DIN}}^{\text {loss }}$, Slawyk et al. 1998). Ammonium regeneration rates $\left(\mathrm{rNH}_{4}, \mu \mathrm{M} \mathrm{d}^{-1}\right)$ were estimated according to Laws (1984):

$$
\mathrm{rNH}_{4}=\frac{\left[\mathrm{NH}_{4}\right]_{0}+\left[\mathrm{NH}_{4}\right]_{\mathrm{F}}}{2 t} \times \ln \left(\frac{R_{0(\mathrm{NH} 4)}}{R_{\mathrm{F}(\mathrm{NH} 4)}}\right)
$$

where $\left[\mathrm{NH}_{4}\right]_{0}$ and $\left[\mathrm{NH}_{4}\right]_{\mathrm{F}}$ represent the initial and final concentrations of ammonium during the incubation experiment, and $R_{0(\mathrm{NH} 4)}$ and $R_{\mathrm{F}(\mathrm{NH} 4)}$ are the initial and final excess enrichments in ${ }^{15} \mathrm{NH}_{4}{ }^{+}$for the incubation period.

Nitrification rates $\left(\mathrm{rNO}_{3}, \mu \mathrm{M} \mathrm{d} \mathrm{d}^{-1}\right)$ were computed according to Raimbault et al. (1999)

$$
\mathrm{rNO}_{3}=\frac{R_{\mathrm{NO} 3}}{R_{\mathrm{NH} 4} \times t} \times\left[\mathrm{NO}_{3}\right]
$$

where $R_{\mathrm{NO} 3}$ is the ${ }^{15} \mathrm{~N}$ atom percent excess enrichment in the $\left(\mathrm{NO}_{3}{ }^{-}+\mathrm{NO}_{2}{ }^{-}\right)$pool, $R_{\mathrm{NH} 4}$ is the mean ${ }^{15} \mathrm{~N}$ atom percent excess enrichment of the $\mathrm{NH}_{4}{ }^{+}$pool, and $\left[\mathrm{NO}_{3}\right]$ is the final $\mathrm{NO}_{3}{ }^{-}$concentration in the filtrate.

The DIN loss rate $\left(\rho_{\mathrm{DIN}}^{\text {loss }}\right)$ as DON was calculated as outlined by Slawyk et al. (1998)

$$
\rho_{\mathrm{DIN}}^{\text {loss }}=\frac{R_{\mathrm{DON}}}{R_{\mathrm{DIN}} \times t} \times[\mathrm{DON}]
$$

where $R_{\mathrm{DON}}$ and $R_{\mathrm{DIN}}$ are the ${ }^{15} \mathrm{~N}$ atom percent excess enrichment of the extracellular DON and DIN pool, respectively, and $[\mathrm{DON}]$ is the final extracellular DON concentration.

Urea concentrations in sea water were not measured, and therefore no urea uptake experiment was performed.

Corrections to $\mathbf{N}$ fluxes. Underestimations of ammonium uptake rates (due to isotopic dilution) were corrected by replacing $R_{\text {DIN }}$ in Eq. (1) with the mean of 
initial and final $R_{\mathrm{NH} 4}$. However, for nitrate uptake rates, high ambient concentrations prevented the detection of a significant signal of isotopic dilution and no correction could be made.

Nitrification can induce overestimations of new production by adding some $\mathrm{NO}_{3}{ }^{-}$to the nitrate pool that derives from what is actually regenerated production (Dugdale \& Goering 1967, Priscu \& Downes 1985, Ward et al. 1989, Dore \& Karl 1996). Consequently, a correction for nitrate-based new production using direct nitrate regeneration measurements was applied (Eq. 5), as previously described by Fernández I. et al. (2005a). The fraction of nitrate that was produced by nitrification was subtracted from total nitrate uptake in order to assess the uptake of 'new' nitrate, as classically defined by Dugdale \& Goering (1967)

$$
\rho_{\text {new }} \mathrm{NO}_{3}=P_{\text {new }}=\rho \mathrm{NO}_{3}-\mathrm{rNO}_{3}
$$

It is worth summarising the concepts used in this study. We define nitrification $\left(\mathrm{rNO}_{3}\right)$ as the oxidation of $\mathrm{NH}_{4}{ }^{+}$to $\mathrm{NO}_{3}{ }^{-}$. Total nitrate assimilation $\left(\mathrm{\rho NO}_{3}\right)$ is assumed to include all sources of nitrate, regenerated as well as new. Corrected nitrate uptake $\left(\rho_{\text {new }} \mathrm{NO}_{3}\right)$ is the uptake of 'truly new' nitrate, which is obtained by separating the terms $\mathrm{\rho NO}_{3}$ and $\mathrm{rNO}_{3}$ (Eq. 5). It represents new production as defined by Dugdale \& Goering (1967). Ammonium regeneration $\left(\mathrm{rNH}_{4}\right)$ is used to correct underestimations of ammonium uptake $\left(\mathrm{\rho NH}_{4}\right)$ and to obtain 'true' ammonium uptake $\left(\rho_{\text {reg }} \mathrm{NH}_{4}\right)$, which corresponds to regenerated production as defined by Dugdale \& Goering (1967). The definition of the $f$ ratio given by Eppley \& Peterson (1979) does not take into account the effect of $\mathrm{N}$ regeneration in the term $\left(\mathrm{\rho NO}_{3}\right.$ $+\rho \mathrm{NH}_{4}$ ), which represents total nitrogen uptake (Eq. 6). In this study, $f$ ratio estimations include corrections to nitrate and ammonium uptake rates (Eq. 7).

$$
\begin{aligned}
& f=\frac{\rho \mathrm{NO}_{3}}{\rho \mathrm{NO}_{3}+\rho \mathrm{NH}_{4}} \\
& f=\frac{\rho \mathrm{NO}_{3}-\mathrm{rNO}_{3}}{\rho \mathrm{NO}_{3}+\rho_{\mathrm{reg}} \mathrm{NH}_{4}}
\end{aligned}
$$

\section{RESULTS}

\section{Hydrological background of the study area}

A full description of the hydrological conditions encountered during POMME can be found in Mémery et al. (2005) and Fernández I. et al. (2005b). The general sea surface temperature (SST) distribution showed values ranging between $13.8^{\circ} \mathrm{C}$ in winter (P1L1) and $14.6^{\circ} \mathrm{C}$ in spring (P2L1). $Z_{\mathrm{m}}$ during winter ranged between $143.6 \pm 57 \mathrm{~m}$ in the north and $124.1 \pm 45 \mathrm{~m}$ in the south. During spring, a general decrease in $Z_{\mathrm{m}}$ was ob- served; however, average values reached $96.3 \pm 40 \mathrm{~m}$ in the southern area. During winter (P1L1), $Z_{\text {eu }}$ varied between $70.1 \pm 9.4 \mathrm{~m}$ in the north and $66.9 \pm 3.7 \mathrm{~m}$ in the south. During spring (P2L1), values of $Z_{\text {eu }}$ decreased to $55.8 \pm 2.5 \mathrm{~m}$ in the north and $49.4 \pm 3.6 \mathrm{~m}$ in the south.

\section{Biogeochemical background}

Average nitrate concentrations during winter (P1L1 and P1L2, Fig. 2) ranged between $4.3 \pm 1.65 \mu \mathrm{M}(5 \mathrm{~m}$ depth) and $7.6 \pm 1.52 \mu \mathrm{M}(200 \mathrm{~m})$. During spring (P2L1, Fig. 2) surface values were $1 \mu \mathrm{M}$ below winter concentrations $(3.3 \pm 1.83 \mu \mathrm{M})$. In deeper layers, no significant evolution was observed compared with winter $(7.6 \pm 1.65 \mu \mathrm{M}$ at $200 \mathrm{~m})$. During P2L2, nitrate concentrations decreased, reaching surface values of $0.4 \mu \mathrm{M}$ (Stn 91) and maximum values of $12 \mu \mathrm{M}$ at $100 \mathrm{~m}$. Ambient $\mathrm{NH}_{4}{ }^{+}$was always detectable. Values obtained during winter (P1L1, Fig. 2) revealed average $\mathrm{NH}_{4}{ }^{+}$concentrations of $0.017 \mu \mathrm{M}$ in the top $60 \mathrm{~m}$, with a subsurface maximum of $0.023 \pm 0.013 \mu \mathrm{M}$ at $30 \mathrm{~m}$. In deeper layers, $\mathrm{NH}_{4}{ }^{+}$concentrations rapidly decreased to values below $0.015 \mu \mathrm{M}$. During P1L2 (Fig. 2), concentrations reached $0.2 \mu \mathrm{M}$ in surface waters (Stn 146). During early spring (P2L1, Fig. 2), average surface values reached $0.065 \pm 0.044 \mu \mathrm{M}$ and a subsurface accumulation of $\mathrm{NH}_{4}{ }^{+}$was observed at $50 \mathrm{~m}(0.15 \pm 0.076 \mu \mathrm{M})$. In deeper layers, ammonium concentrations decreased to $0.023 \pm 0.027 \mu \mathrm{M}$ $(200 \mathrm{~m})$. Maximum concentrations were observed at Stn 91 (P2L2, Fig. 2), where surface values reached $0.13 \mu \mathrm{M}$ and a subsurface peak of $0.47 \mu \mathrm{M}$ was measured at $30 \mathrm{~m}$. Average nitrite concentrations during winter (P1L1) ranged between $0.13 \pm 0.04 \mu \mathrm{M}$ and $0.14 \pm 0.03 \mu \mathrm{M}$ in the top $100 \mathrm{~m}$ (Fig. 2). During P1L2, nitrite concentrations increased, reaching $0.29 \mu \mathrm{M}$ at Stn 146 (30 m). During early spring (P2L1, Fig. 2), values reached $0.15 \pm 0.07 \mu \mathrm{M}$ in surface waters and $0.27 \pm 0.08 \mu \mathrm{M}$ within 80 to $100 \mathrm{~m}$. Between 100 and $200 \mathrm{~m}$ depth, concentrations decreased to $0.04 \pm$ $0.05 \mu \mathrm{M}$. The $\mathrm{NO}_{2}^{-}$subsurface maximum was $50 \mathrm{~m}$ deeper than the ammonium accumulation observed in Fig. 2. During late spring (P2L2), maximum nitrite values reached $0.43 \mu \mathrm{M}(100 \mathrm{~m})$, while surface values (0.06 $\mu \mathrm{M}$ at Stn 91) were in the range of average spring concentrations (P2L1).

\section{Nitrate uptake and nitrification rates}

$$
\text { Nitrate uptake rates }\left(\rho \mathrm{NO}_{3}\right)
$$

Average nitrate uptake rates obtained during winter (P1L1) were close to $0.04 \pm 0.03 \mu \mathrm{M} \mathrm{d}^{-1}$ in surface 
waters (max. $0.14 \mu \mathrm{M} \mathrm{d}^{-1}$ ), and increased at $20 \mathrm{~m}$ depth (max. $0.23 \mu \mathrm{M} \mathrm{d}^{-1}$, Fig. 3). In deeper layers, $\mathrm{\rho NO}_{3}$ reached $0.007 \pm 0.01 \mu \mathrm{M} \mathrm{d}^{-1}$. During P1L2, rates of $\mathrm{NNO}_{3}$ ranged between 0.05 and $0.09 \mu \mathrm{M} \mathrm{d} \mathrm{d}^{-1}$ and exceeded $0.1 \mu \mathrm{M} \mathrm{d}^{-1}$ at $20 \mathrm{~m}$ depth (Fig. 3). Maximum values were observed at Stn $90\left(0.28 \mu \mathrm{M} \mathrm{d}^{-1}\right.$ at $\left.20 \mathrm{~m}\right)$. During spring (P2L1), $\rho \mathrm{NO}_{3}$ was higher than in winter (Fig. 3), and occurred mainly in surface waters. Average values reached $0.15 \pm 0.064 \mu \mathrm{M} \mathrm{d}^{-1}$ at $5 \mathrm{~m}$ (max. $0.28 \mu \mathrm{M} \mathrm{d}^{-1}$ ) and decreased to $0.018 \pm 0.009 \mu \mathrm{M} \mathrm{d}^{-1}$ at $50 \mathrm{~m}$ (max. $0.03 \mu \mathrm{M} \mathrm{d}^{-1}$ ). Stations of P2L2 followed the same trend, with maximum values at Stn $91\left(0.2 \mu \mathrm{M} \mathrm{d}^{-1}\right.$ in surface waters).
Nitrification rates and corrected nitrate assimilation

Nitrification $\left(\mathrm{rNO}_{3}\right)$ during our study was as high in surface layers as in deeper waters, and occurred in well-lit waters as well as at the base of the euphotic zone (Fig. 3). Winter rates (P1L1) reached $0.009 \pm$ $0.015 \mu \mathrm{M} \mathrm{d}^{-1}$ in surface waters (max. $0.017 \mu \mathrm{M} \mathrm{d}^{-1}$ ) and increased slightly with depth to $0.015 \pm 0.008 \mu \mathrm{M} \mathrm{d}^{-1}$ (Fig. 3). Two exceptionally high rates were obtained in the top $20 \mathrm{~m}$ : one at $\operatorname{Stn} 2$ in the southern area $\left(0.077 \mu \mathrm{M} \mathrm{d}^{-1}\right)$ and the other at Stn 18 in the north $\left(0.069 \mu \mathrm{M} \mathrm{d}^{-1}\right)$. Integrated rates for P1L1 reached $0.89 \mathrm{mmol} \mathrm{m}^{-2} \mathrm{~d}^{-1}$ (Table 1). During P1L2, nitrification

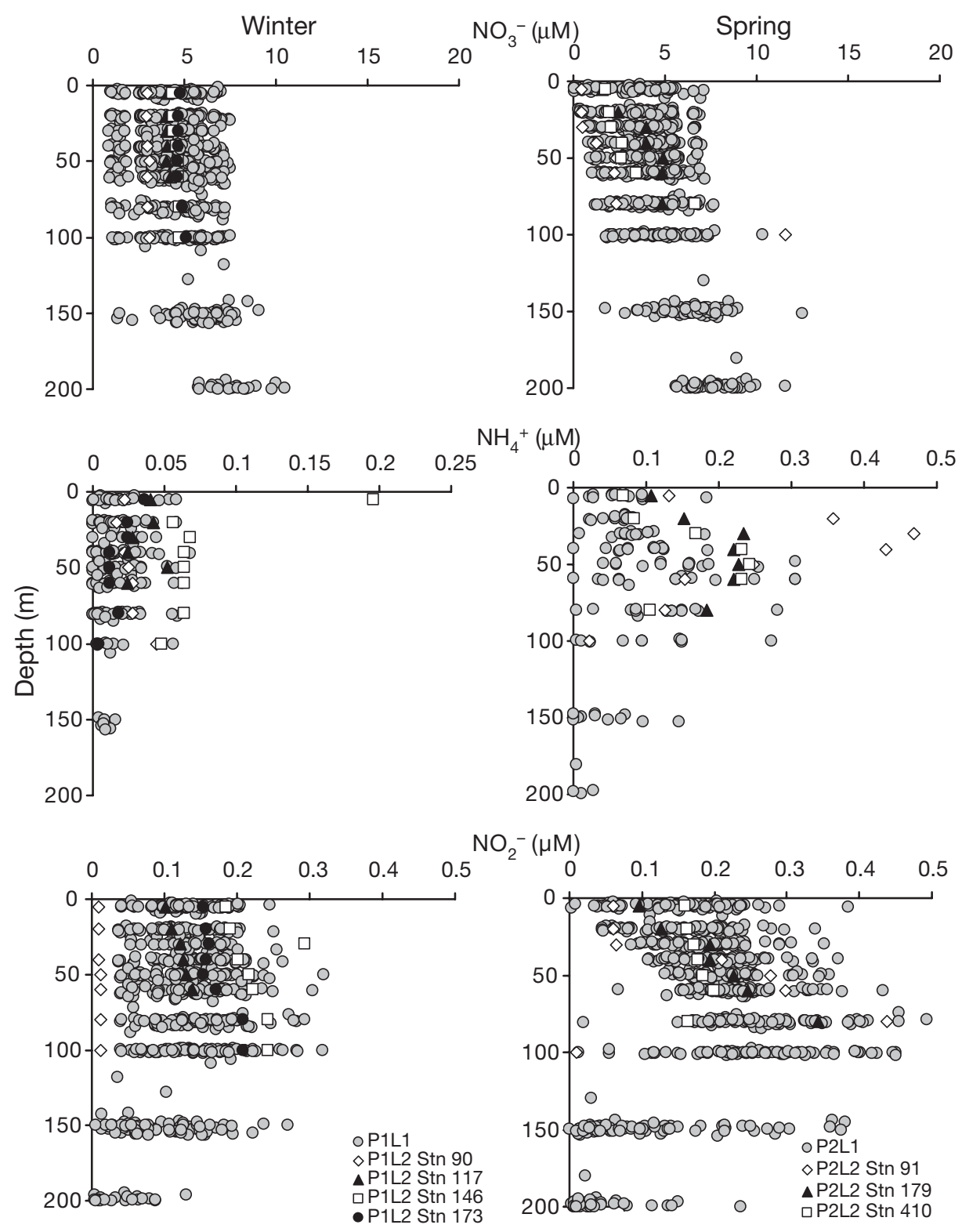

Fig. 2. Vertical distributions of $\mathrm{NO}_{3}{ }^{-}\left(\mu \mathrm{M}\right.$, top), $\mathrm{NH}_{4}{ }^{+}\left(\mu \mathrm{M}\right.$, centre) and $\mathrm{NO}_{2}{ }^{-}(\mu \mathrm{M}$, bottom). o: first leg data. Half scale was used for $\mathrm{NH}_{4}^{+}$winter data 


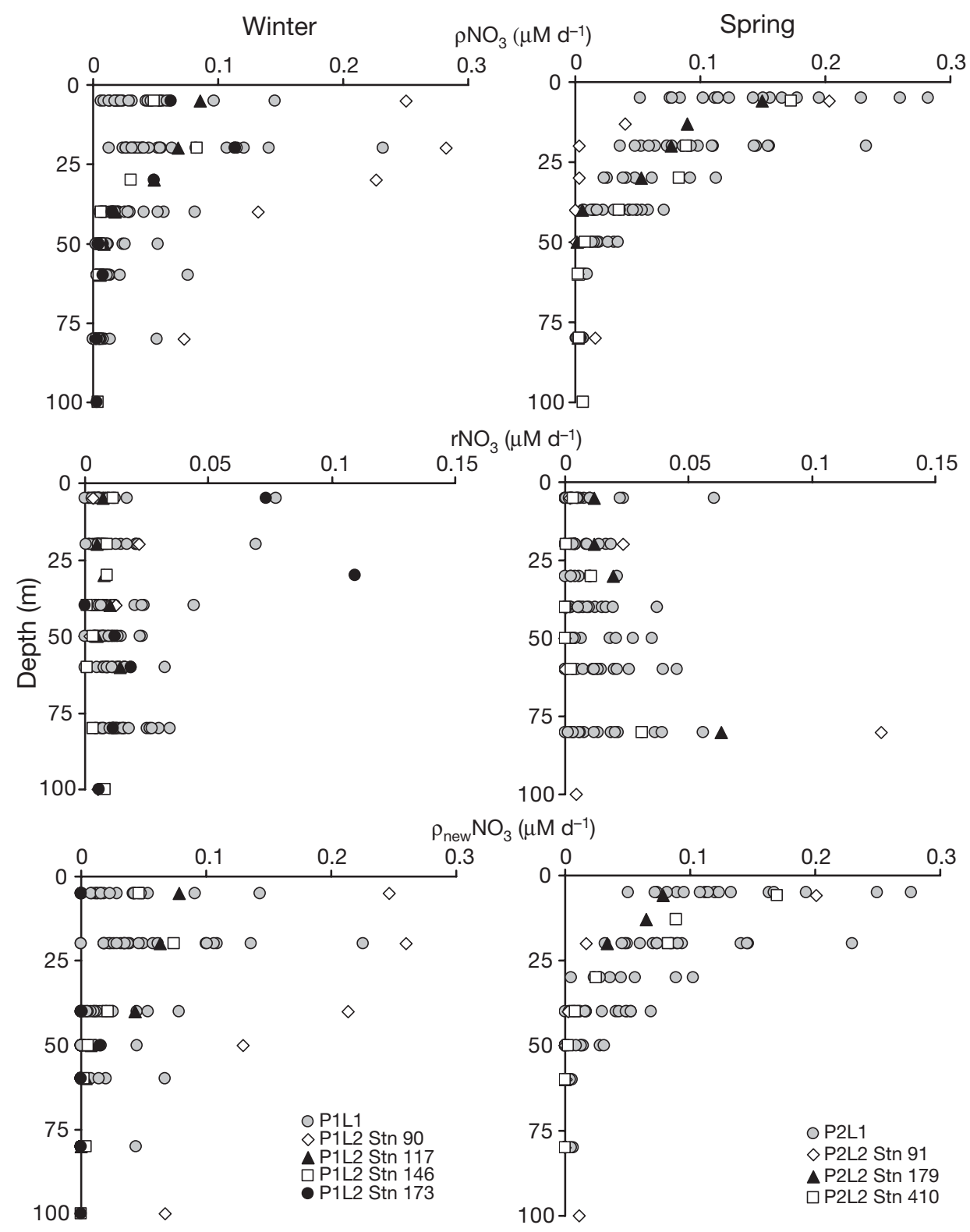

Fig. 3. Vertical distributions of total nitrate uptake $\left(\mathrm{NO}_{3}\right.$, top), nitrification $\left(\mathrm{rNO}_{3}\right.$, centre) and corrected new nitrate uptake $\left(\rho_{\text {new }} \mathrm{NO}_{3}\right.$, bottom) during winter and spring 2001. O: first leg data

rates in the top $30 \mathrm{~m}$ ranged from between 0.02 and $0.025 \mathrm{\mu M} \mathrm{d}^{-1}$ at Stns 91,117 and 146 to maximum values of between 0.073 and $0.109 \mu \mathrm{M} \mathrm{d}^{-1}$ at Stn 173 (Fig. 3). In deeper layers, $\mathrm{rNO}_{3}$ decreased to $0.018 \mu \mathrm{M}$ $\mathrm{d}^{-1}(60 \mathrm{~m})$ and $0.005 \mu \mathrm{M} \mathrm{d}^{-1}(100 \mathrm{~m})$. Integrated $\mathrm{rNO}_{3}$ ranged from $0.3 \mathrm{mmol} \mathrm{m}^{-2} \mathrm{~d}^{-1}$ at Stn 146 to $2.67 \mathrm{mmol}$ $\mathrm{m}^{-2} \mathrm{~d}^{-1}$ at Stn 173 (Table 1). The spring season (P2L1, Fig. 3) exhibited surface nitrification rates close to winter values $\left(0.009 \pm 0.014 \mu \mathrm{M} \mathrm{d}^{-1}\right)$ with an increase towards southern stations ( $\max 0.02$ to $0.06 \mu \mathrm{M} \mathrm{d}^{-1}$ ). In deeper layers, nitrification rates increased to $0.016 \pm$ $0.016 \mu \mathrm{M} \mathrm{d}^{-1}$ (max. $0.06 \mu \mathrm{M} \mathrm{d}^{-1}$ at $80 \mathrm{~m}$ ). Integrated nitrification was also close to winter values $(0.88 \mathrm{mmol}$ $\mathrm{m}^{-2} \mathrm{~d}^{-1}$, Table 1). During P2L2 (Fig. 3), nitrification in the top $50 \mathrm{~m}$ was close to $0.03 \mu \mathrm{M} \mathrm{d}^{-1}$ and increased at $80 \mathrm{~m}\left(0.127 \mu \mathrm{M} \mathrm{d}^{-1}\right.$, Stn 91). Nevertheless, integrated nitrification rates exhibited high values in surface waters at Stn $179\left(\sum \mathrm{rNO}_{3} \approx 2.34 \mathrm{mmol} \mathrm{m}^{-2} \mathrm{~d}^{-1}\right.$, Table 1$)$. The lowest integrated rate was found at Stn 410 (0.14 $\mathrm{mmol} \mathrm{m}^{-2} \mathrm{~d}^{-1}$, Table 1).

After correcting $\mathrm{NNO}_{3}$ for nitrification, the influence of nitrification on nitrate uptake seems to be clear. Winter (P1L1) values of $\rho_{\text {new }} \mathrm{NO}_{3}$ (Fig. 3) were $30 \%$ lower than $\rho \mathrm{NO}_{3}$, reaching $0.031 \pm 0.03 \mu \mathrm{M} \mathrm{d}^{-1}$ in sur- 
Table 1. Integrated rates $($ at $80 \mathrm{~m})$ of nitrate uptake $\left(\Sigma_{\rho \mathrm{NO}}\right)$, nitrification $\left(\sum \mathrm{rNO}_{3}\right)$, 'new' nitrate uptake $\left(\Sigma_{\rho_{\text {new }}} \mathrm{NO}_{3}\right)$, ammonium uptake $\left(\Sigma \rho \mathrm{NH}_{4}\right)$, ammonium regeneration $\left(\Sigma_{\mathrm{rNH}}\right)$, and corrected ammonium uptake $\left(\sum_{\text {reg }} \mathrm{NH}_{4}\right)$. Integrated values were obtained from average profiles for the first leg of POMME 1 and POMME 2, and from discrete profiles for stations of the second leg (P1L2 and P2L2). Total $\mathrm{\rho NH}_{4}$ represents an estimation of ammonium assimilation by autotrophic and heterotrophic processes, including DON excretion

\begin{tabular}{|c|c|c|c|c|c|c|c|c|}
\hline $\begin{array}{l}\text { Cruise/ } \\
\text { station }\end{array}$ & $\underset{\left(\mathrm{mmol} \mathrm{m}^{-2} \mathrm{~d}^{-1}\right)}{\sum_{\mathrm{NNO}_{3}}}$ & $\underset{\left(\mathrm{mmol} \mathrm{m}^{-2} \mathrm{~d}^{-1}\right)}{\sum_{\mathrm{rNO}_{3}}}$ & $\underset{\left(\mathrm{mmol} \mathrm{m}^{-2} \mathrm{~d}^{-1}\right)}{\sum_{\rho_{\text {new }} \mathrm{NO}_{3}}}$ & $\begin{array}{c}\sum_{\rho_{\text {new }} \mathrm{NO}_{3} \mathrm{Vs} .} \\
\sum_{\mathrm{pNO}_{3}(\%)}\end{array}$ & $\begin{array}{c}\sum \mathrm{\rho NH}_{4} \\
\left(\mathrm{mmol} \mathrm{m}^{-2} \mathrm{~d}^{-1}\right)\end{array}$ & $\underset{\left(\mathrm{mmol} \mathrm{m}^{-2} \mathrm{~d}^{-1}\right)}{\mathrm{rnH}_{4}}$ & $\begin{array}{c}\sum_{\text {total }} \rho \mathrm{NH}_{4} \\
\left(\mathrm{mmol} \mathrm{m}^{-2} \mathrm{~d}^{-1}\right)\end{array}$ & $\underset{\left(\mathrm{mmol} \mathrm{m}^{-2} \mathrm{~d}^{-1}\right)}{\sum_{\rho_{\mathrm{reg}} \mathrm{NH}_{4}}}$ \\
\hline P1L1 (winter) & 2.33 & 0.89 & 1.44 & 38 & 1.35 & 2.64 & 6.5 & 4.89 \\
\hline P1L2/Stn 90 & 14.6 & 0.72 & 13.8 & 5.5 & 2.5 & 1.88 & 4.3 & 3.36 \\
\hline P1L2/Stn 117 & 2.6 & 0.5 & 2.1 & 20 & 3.5 & 1.01 & 4.2 & 3.6 \\
\hline P1L2/Stn 146 & 2.06 & 0.31 & 1.75 & 15 & 3.83 & 1.69 & 6.7 & 5.6 \\
\hline P1L2/Stn 173 & 2.88 & 2.67 & 0.21 & 93 & 3.38 & 3.3 & 10.4 & 5.2 \\
\hline P2L1 (spring) & 4.45 & 0.88 & 3.5 & 21 & 3.32 & 7.65 & 17.2 & 11.9 \\
\hline P2L2/Stn 91 & 3.15 & 1.72 & 1.43 & 45.4 & 5.56 & 5.5 & 13.6 & 6.7 \\
\hline P2L2/Stn 179 & 3.34 & 2.34 & 1 & 70 & 4.35 & 1.47 & 14.3 & 5.8 \\
\hline P2L2/Stn 410 & 3.53 & 0.14 & 3.4 & 4 & 3.3 & 3.6 & 12.1 & 4.5 \\
\hline
\end{tabular}

face waters (max. $0.014 \mu \mathrm{M} \mathrm{d}^{-1}$ ) and $0.054 \pm 0.05 \mu \mathrm{M}$ $\mathrm{d}^{-1}$ at $20 \mathrm{~m}$. In deeper layers, values decreased to $0.002 \pm 0.009 \mu \mathrm{M} \mathrm{d}^{-1}$. During P1L2, $\rho_{\text {new }} \mathrm{NO}_{3}$ was as much as $20 \%$ lower than $\rho \mathrm{NO}_{3}$, except at Stn 173 where $\rho_{\text {new }} \mathrm{NO}_{3}$ was close to 0 , suggesting that nearly $100 \%$ of the assimilated nitrate came from nitrification. Gathering all data, the integration of winter profiles (P1L1) revealed a $38 \%$ contribution of regenerated nitrate to total nitrate uptake. For P1L2 stations, correcting nitrate uptake rates for nitrification induced significant variations in $\rho_{\text {new }} \mathrm{NO}_{3}$ compared with $\rho \mathrm{NO}_{3}$ (5.5 to $93 \%$, Table 1). During spring (Fig. 3), surface values of $\rho_{\text {new }} \mathrm{NO}_{3}$ reached $0.13 \pm 0.062 \mu \mathrm{M} \mathrm{d}^{-1}$ and nitrate regeneration accounted for $10 \%$ of $\rho^{-1} \mathrm{NO}_{3}$. Below $50 \mathrm{~m}$ depth, $\rho_{\text {new }} \mathrm{NO}_{3}$ was close to 0 , indicating that $100 \%$ of the assimilated nitrate came from nitrification. During P2L2, $\rho_{\text {new }} \mathrm{NO}_{3}$ showed the same trend, with the exception of Stn 179 where $50 \%$ of surface $\rho \mathrm{NO}_{3}$ was supported by regenerated nitrate. Integrated $\mathrm{rNO}_{3}$ values during spring (P2L1) showed a $21 \%$ contribution of nitrification to total nitrate uptake $\left(\rho_{\text {new }} \mathrm{NO}_{3} \approx 3.5 \mathrm{mmol}\right.$ $\mathrm{m}^{-2} \mathrm{~d}^{-1}$ ); contributions during late spring (P2L2) ranged from $4 \%$ at Stn 410 to $70 \%$ at Stn 179 (Table 1).

\section{Ammonium uptake and ammonium regeneration}

\section{Ammonium uptake $\left(\rho \mathrm{NH}_{4}\right)$}

During winter (P1L1), average $\mathrm{NNH}_{4}$ reached $0.02 \pm$ $0.013 \mu \mathrm{M} \mathrm{d}^{-1}$ in surface waters (max. $0.06 \mu \mathrm{M} \mathrm{d}^{-1}$ ), and decreased with depth to $0.007 \pm 0.005 \mu \mathrm{M} \mathrm{d}^{-1}$ (Fig. 4). During P1L2, $\rho \mathrm{NH}_{4}$ increased in surface waters and ranged between $0.052 \mu \mathrm{M} \mathrm{d}^{-1}$ (Stn 90) and $0.135 \mu \mathrm{M}$ $\mathrm{d}^{-1}$ (Stn 146). During spring, $\rho \mathrm{NH}_{4}$ (P2L1, Fig. 4) was high compared with winter. Average surface rates reached $0.069 \pm 0.024 \mu \mathrm{M} \mathrm{d}^{-1}$ (max. $0.12 \mu \mathrm{M} \mathrm{d}^{-1}$ ), while minimum values $\left(0.012 \pm 0.006 \mu \mathrm{M} \mathrm{d}^{-1}\right)$ were observed at $80 \mathrm{~m}$. During $\mathrm{P} 2 \mathrm{~L} 2$, surface $\rho \mathrm{NH}_{4}$ values ranged between 0.084 (Stn 410) and $0.124 \mu \mathrm{M} \mathrm{d}^{-1}$ (Stn 179). In deeper layers $(30 \mathrm{~m})$, maximum rates reached $0.197 \mu \mathrm{M} \mathrm{d}^{-1}$ (Stn 91).

\section{$\mathrm{NH}_{4}{ }^{+}$regeneration}

During measurements of $\rho^{15} \mathrm{NH}_{4}$, tracer dilution may occur due to the appearance of ${ }^{14} \mathrm{NH}_{4}{ }^{+}$coming from regeneration processes mediated by microzooplankton and bacteria. Results revealed the presence of active $\mathrm{rNH}_{4}$ during our study, with winter (P1L1) average values close to $0.17 \mu \mathrm{M} \mathrm{d}^{-1}$ and maximum values of $0.41 \mu \mathrm{M} \mathrm{d}^{-1}$ at $20 \mathrm{~m}$ depth (Stn 2). Integrated rates of winter $\mathrm{rNH}_{4}$ reached $2.64 \mathrm{mmol} \mathrm{m}^{-2} \mathrm{~d}^{-1}$ (Table 1). During P1L2 (Fig. 4), $\mathrm{rNH}_{4}$ in surface waters varied between 0.061 (Stn 179) and $0.081 \mu \mathrm{M} \mathrm{d}^{-1}$ (Stn 146), and decreased with depth to $0.01 \mu \mathrm{M} \mathrm{d}^{-1}$ (60 to $80 \mathrm{~m}$ ). Higher rates were observed at Stn 173 (0.08 and $0.1 \mu \mathrm{M} \mathrm{d}^{-1}$ ), for which integrated $\mathrm{rNH}_{4}$ reached $3.3 \mathrm{mmol} \mathrm{m}^{-2} \mathrm{~d}^{-1}$ (Table 1). During spring (P2L1, Fig. 4), $\mathrm{rNH}_{4}$ was high compared with winter, reaching $0.15 \mu \mathrm{M} \mathrm{d}^{-1}$ in surface waters (average value $0.072 \pm$ $\left.0.1 \mu \mathrm{M} \mathrm{d}^{-1}\right)$. Maximum rates were obtained at $\operatorname{Stn} 2$ $\left(0.423 \mu \mathrm{M} \mathrm{d}^{-1}\right)$ and decreased to $0.3 \mu \mathrm{M} \mathrm{d}^{-1}$ below $20 \mathrm{~m}$ depth. The integrated rate for spring (P2L1) reached $7.65 \mathrm{mmol} \mathrm{m}^{-2} \mathrm{~d}^{-1}$. During P2L2, $\mathrm{rNH}_{4}$ was lower (Fig. 4); however, it showed a subsurface maximum of $0.2 \mu \mathrm{M} \mathrm{d}^{-1}$ (20 to $30 \mathrm{~m}$ ) at Stns 91 and 410 . Integrated rates ranged between 1.47 and $5.5 \mathrm{mmol} \mathrm{m}^{-2} \mathrm{~d}^{-1}$ (Table 1).

$$
\text { Corrected ammonium uptake }\left(\rho_{\text {reg }} \mathrm{NH}_{4}\right)
$$

The most significant difference between corrected ammonium uptake rates $\left(\rho_{\text {reg }} \mathrm{NH}_{4}\right)$ and $\rho \mathrm{NH}_{4}$ occurred 


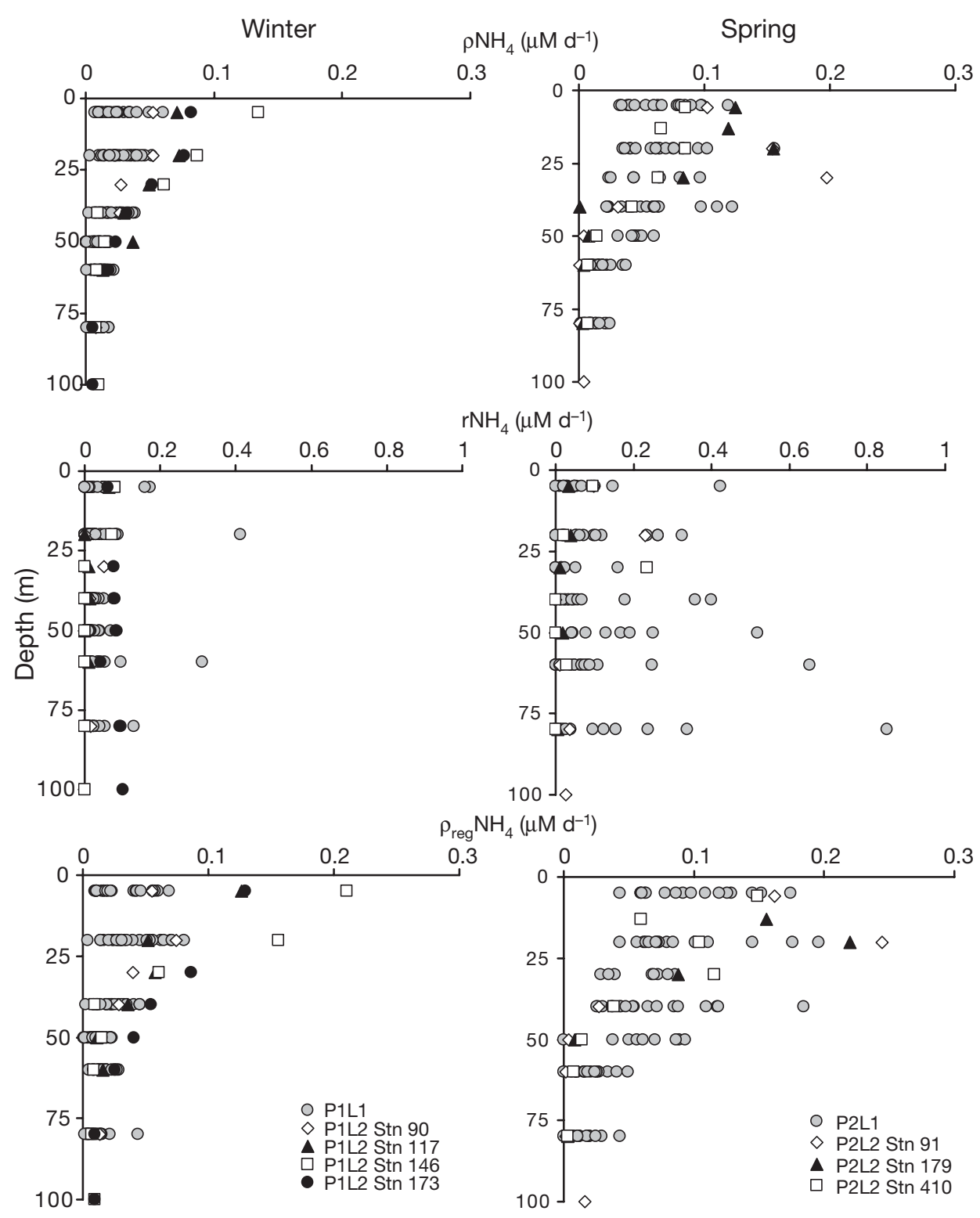

Fig. 4. Vertical distributions of ammonium uptake $\left(\mathrm{NHH}_{4}\right.$, top), ammonium regeneration $\left(\mathrm{rNH}_{4}\right.$, centre) and corrected ammonium uptake $\left(\rho_{\text {Reg }} \mathrm{NH}_{4}\right.$, bottom) during winter and spring. O: first leg data

in the top $50 \mathrm{~m}$ of the water column (Fig. 4). During winter $(\mathrm{P} 1 \mathrm{~L} 1)$, corrected ammonium uptake $\left(\rho_{\text {reg }} \mathrm{NH}_{4}\right)$ was $27 \%$ higher than originally estimated $\left(\rho \mathrm{NH}_{4}\right.$, Fig. 4$)$. Average values of $\rho_{\text {reg }} \mathrm{NH}_{4}$ reached $0.03 \pm 0.019 \mu \mathrm{M} \mathrm{d}^{-1}$ in surface layers (max. $0.069 \mu \mathrm{M} \mathrm{d}^{-1}$ at Stn 37) and $0.038 \pm 0.02 \mu \mathrm{M} \mathrm{d}^{-1}$ at $20 \mathrm{~m}$ depth $\left(\max .0 .08 \mu \mathrm{M} \mathrm{d}^{-1}\right.$ at Stn 2). Integrated $\rho_{\text {reg }} \mathrm{NH}_{4}$ reached $4.89 \mathrm{mmol} \mathrm{m}^{-2} \mathrm{~d}^{-1}$ (Table 1). Importantly, $\Sigma \rho_{\text {reg }} \mathrm{NH}_{4}$ values from stations of the second leg ranged from 3 to $6 \mathrm{mmol} \mathrm{m}^{-2} \mathrm{~d}^{-1}$, largely exceeding uncorrected $\mathrm{\rho NH}_{4}$ values from the same period (Table 1). During spring (P2L1, Fig. 4), $\rho_{\text {reg }} \mathrm{NH}_{4}$ was $30 \%$ higher than $\mathrm{\rho NH}_{4}$ in surface waters (maximum $\rho_{\text {reg }} \mathrm{NH}_{4} \approx 0.175 \mu \mathrm{M} \mathrm{d}^{-1}$ ). At $20 \mathrm{~m}$, values reached
$0.19 \mu \mathrm{M} \mathrm{d}^{-1}$ and remained high between 30 and $50 \mathrm{~m}$ depth. Integrated rates of $\rho_{\text {reg }} \mathrm{NH}_{4}$ were higher than in winter and also exceeded $\mathrm{\rho NH}_{4}$ values $\left(11.9 \mathrm{mmol} \mathrm{m}^{-2}\right.$ $\mathrm{d}^{-1}$ for P2L1 and 4 to $7 \mathrm{mmol} \mathrm{m} \mathrm{m}^{-2} \mathrm{~d}^{-1}$ for P2L2, Table 1).

\section{Observations of high ammonium uptake in the $<\mathrm{GF} / \mathrm{F}$ fraction}

The term 'total $\mathrm{\rho NH}_{4}$ ' represents an estimation of ammonium assimilation by autotrophic and heterotrophic processes, and includes DON excretion (Table 1). In most cases, this value was very close to $\rho_{\text {reg }} \mathrm{NH}_{4}$ 
(Table 1). However, during late spring (P2L2), differences exceeded $50 \%$ (Table 2 ). In such cases an excess of tracer loss was observed during ${ }^{15} \mathrm{NH}_{4}{ }^{+}$incubations, which was linked to small size particles $(<0.7 \mu \mathrm{m})$ enriched in ${ }^{15} \mathrm{~N}$. Such particles can be included in the $\mathrm{DON}+\mathrm{PON}_{<\mathrm{GF} / \mathrm{F}}$ fraction, defined as DON' by Slawyk \& Raimbault (1995). For those authors, the fluxes associated with this pool represented a loss of tracer from the DIN compartment to the bacterial compartment, in the form of organic nitrogen. Fig. 5 synthesizes comparisons made between $\rho_{\text {DIN }}^{\text {loss }}$ (referred to as DON loss) and $\rho_{\mathrm{reg}} \mathrm{NH}_{4}$ during P1L2 and P2L2 for stations with similar hydrological characteristics (see also Mémery et al. 2005). Rates of $\rho_{\text {DIN }}^{\text {loss }}$ during P1L2 did not exceed $10 \%$ of $\mathrm{NH}_{4}$ assimilation. However, rates for P2L2 $\left(0.096 \mu \mathrm{M} \mathrm{d}^{-1}\right)$ were 8 times higher (Fig. 5). Moreover, $\rho_{\text {DIN }}^{\text {loss }}$ obtained during P2L2 exceeded former estimations found in the literature by at least $50 \%$ (Table 2). In such cases, comparisons were made between $\rho_{\text {DIN }}^{\text {loss }}$ values obtained from the $<0.7$ and $<0.2 \mu \mathrm{m}$ size fractions after single $(\mathrm{GF} / \mathrm{F})$ and double filtration $(\mathrm{GF} / \mathrm{F}$ and $0.2 \mu \mathrm{m}$ filters; see 'Materials and methods'). Organic nitrogen that passed through GF/F filters and was retained by the $0.2 \mu \mathrm{m}$ membrane could reach $80 \%$ (Fig. 6). This organic nitrogen can be linked to particles that actively assimilated ${ }^{15} \mathrm{NH}_{4}{ }^{+}$or to the re-

Table 2. Data of $\rho_{\text {DIN }}^{\text {loss }}\left(\mu \mathrm{M} \mathrm{d}^{-1}\right)$ obtained from literature and field experiments (this study). 'Total $\rho \mathrm{NH}_{4}: \rho_{\text {reg }} \mathrm{NH}_{4}{ }^{\prime}$ represents the ratio between ammonium assimilation (corrected for ammonium regeneration) and total $\mathrm{NH}_{4}$ uptake (taking DON excretion into account)

\begin{tabular}{|lccc|}
\hline Location & $\rho_{\text {DIN }}^{\text {loss }}$ & Total $\rho \mathrm{NH}_{4}: \rho_{\text {reg }} \mathrm{NH}_{4}\left(\mu \mathrm{M} \mathrm{d}^{-1}\right)$ & Study \\
\hline NE Atlantic & $0.012 \pm 0.015$ & $0.6 \pm 0.2$ & POMME 1 Leg 2 (P1L2) \\
NE Atlantic & $0.096 \pm 0.136$ & $0.4 \pm 0.3$ & POMME 2 Leg 2 (P2L2) \\
Equatorial Pacific & $0-0.004$ & 0.85 & Slawyk et al. (1998) \\
Mediterranean Sea (Gulf of Lions) & $0-0.035$ & 0.76 & Diaz \& Raimbault (2000) \\
\hline
\end{tabular}

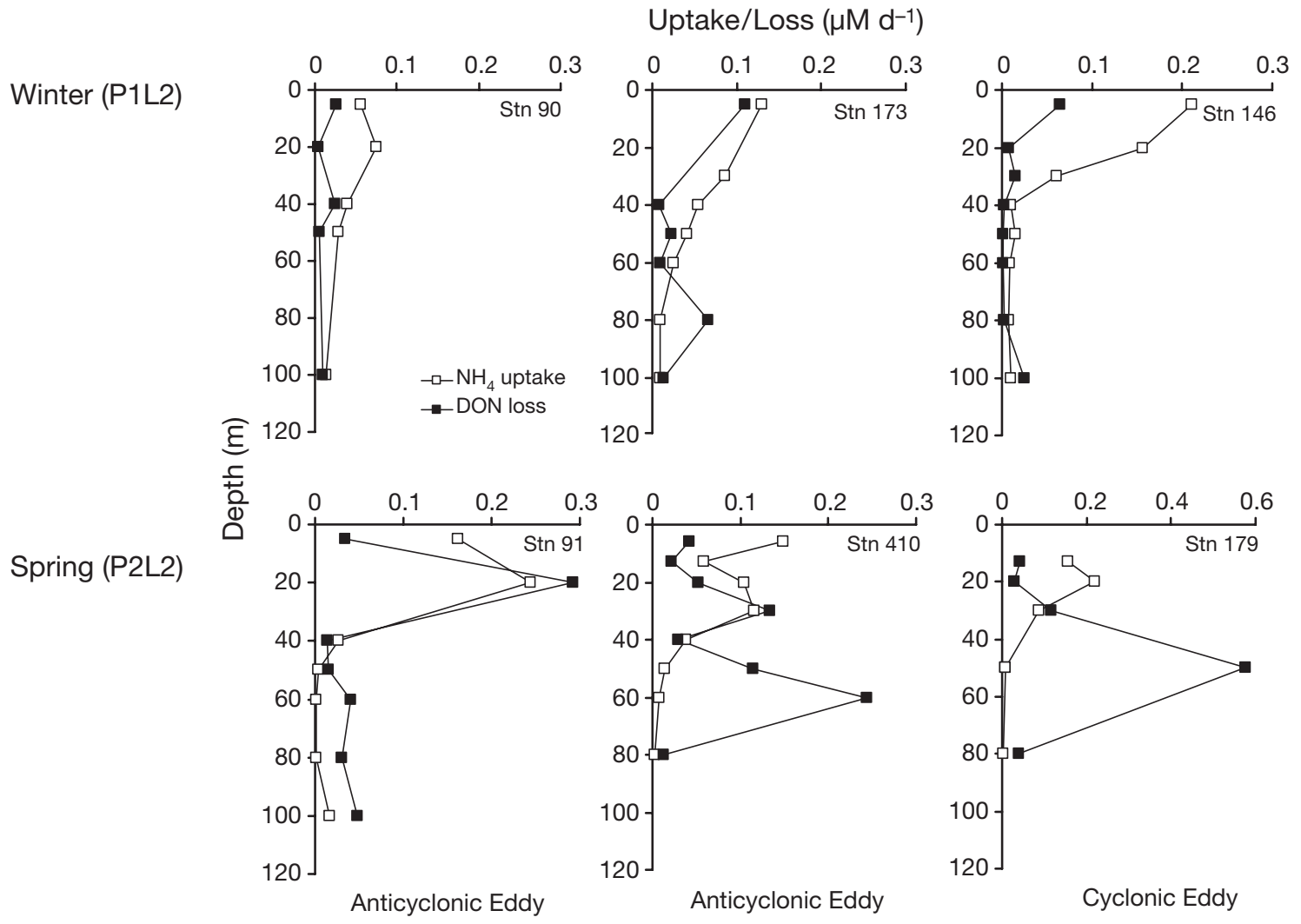

Fig. 5. Corrected ammonium uptake $\left(\rho_{\text {reg }} \mathrm{NH}_{4}\right.$; noted as $\mathrm{NH}_{4}$ uptake, $\square$ ) and $\rho_{\text {DIN }}^{\text {loss }}$ (noted as DON loss, $\left.\mathbf{\square}\right)$ for stations sampled during winter (P1L2, top) and spring (P2L2, bottom). Hydrological characteristics of stations are given; Stn 179 at double scale 


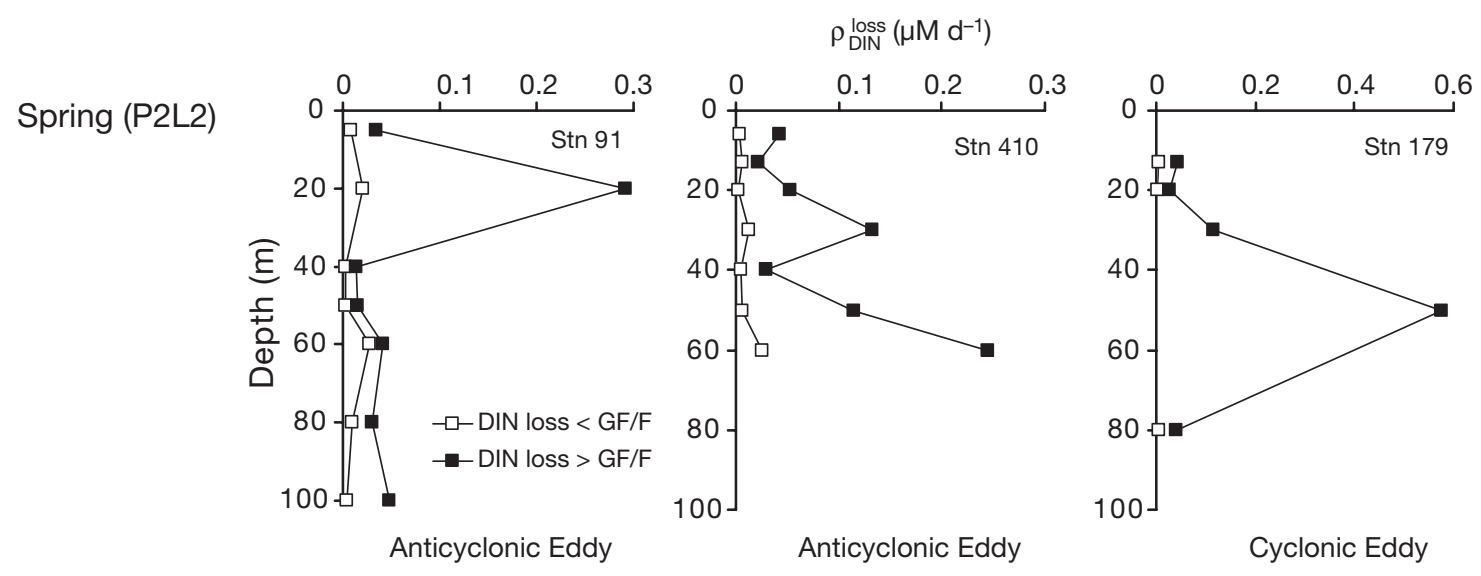

Fig. 6. Vertical distributions of $\rho_{\text {DIN }}^{\text {loss }}$ during spring (P2L2, Stns 91, 179 and 410) after successive filtrations onto GF/F filters ( $\left.\mathbf{\square}\right)$ and $0.2 \mu \mathrm{m}$ membranes ( $\square$ ). Hydrological characteristics of stations are given; Stn 179 at double scale

lease of $\mathrm{DO}^{15} \mathrm{~N}$ during the incubation process. Stn 91 gave the highest values of $\rho_{\text {DIN }}^{\text {loss }}$ in the $0.2 \mu \mathrm{m}$ fraction $\left(0.078 \mu \mathrm{M} \mathrm{d}^{-1}\right.$ at $\left.30 \mathrm{~m}\right)$, which accounted for $25 \%$ of the maximum value obtained after GF/F filtration (Fig. 6) and represented $25 \%$ of total ammonium uptake. Subsurface peaks were also observed in deeper layers (Stns 91 and 410). Therefore, the use of GF/F filters failed to retain a significant fraction of small particles (labelled with ${ }^{15} \mathrm{NH}_{4}{ }^{+}$) during the spring bloom. The vertical distribution of tracer losses as 'DON + particles $<\mathrm{GF} / \mathrm{F}^{\prime}$ indicates a significant contribution of bacteria from the $<0.7 \mu \mathrm{m}$ size fraction, as previously suggested by Altabet (1990). Results from $<0.2 \mu \mathrm{m}$ filtrates showed that less than $10 \%$ of ${ }^{15} \mathrm{~N}$ was lost as during P2L2 (as previously stated by Slawyk et al. 2000) and that tracer accumulated in the $<\mathrm{GF} / \mathrm{F}$ fraction due to ${ }^{15} \mathrm{~N}$ assimilation by small particles. Ammonium uptake rates during late spring 2001 could therefore be underestimated.

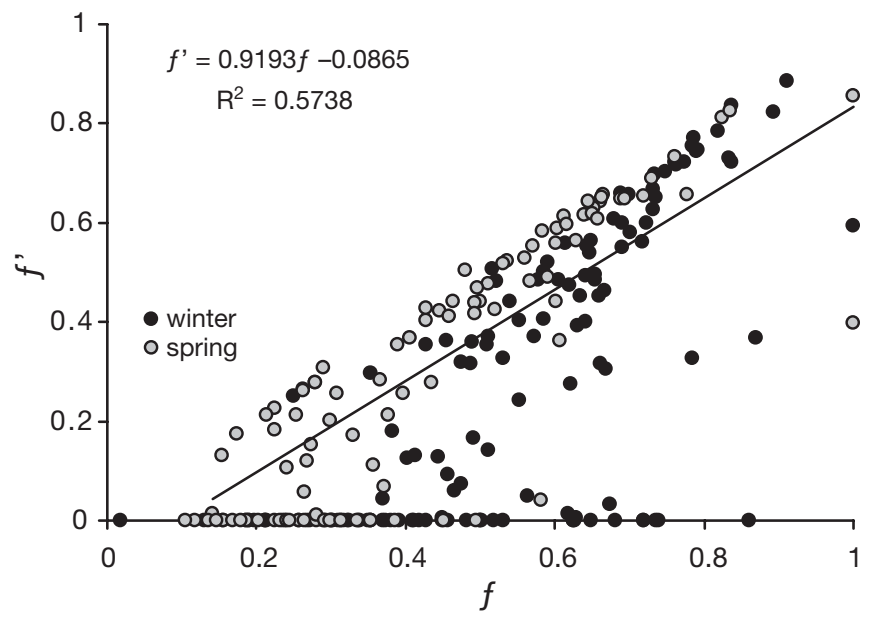

Fig. 7. Relationship between classical $f$ (see Eppley \& Peterson 1979; our Eq. 6) and corrected $f^{\prime}$ (see Eq. 7) ratio values for winter $(\bullet)$ and spring $(0)$. Values below 0.1 were excluded from the linear relationship presented in this figure

\section{Regeneration of $\mathbf{N}$ and $\boldsymbol{f}$ ratio calculations}

Fluxes of nitrification and ammonium regeneration caused a decrease in estimations of 'new nitrate' assimilation (new production) and an increase in ammonium uptake (regenerated production). An immediate step is to evaluate the effect of $\mathrm{rNO}_{3}$ and $\mathrm{rNH}_{4}$ on the $f$ ratio (Fig. 7). Comparison between classical $(f)$ and corrected values $\left(f^{\prime}\right)$ showed a linear relationship $\left(f^{\prime}=0.9193 f-0.0865, \mathrm{R}^{2}=0.5738\right)$, with values of $f$ roughly $10 \%$ higher than $f^{\prime}$ (however, discrepancies can exceed $40 \%$ ). There are several points for which $f^{\prime}$ values dropped to 0 (33\% of all observations), which corresponded to stations with high nitrification rates. In those cases, $\mathrm{rNO}_{3}$ could support $100 \%$ of nitrate uptake, and new production (in the sense of Dugdale \& Goering 1967) dropped to 0 , as $\operatorname{did} f^{\prime}$.

\section{DISCUSSION}

\section{General observations}

This study represents a rigorous approach that systematically takes into account nitrification and ammonium regeneration in calculations of DIN uptake rates $\left(\mathrm{NO}_{3}{ }^{-}\right.$and $\left.\mathrm{NH}_{4}{ }^{+}\right)$. Additionally, it provides an objective methodological approach to the difficulty of estimating DON excretion by conventional ${ }^{15} \mathrm{~N}$ techniques. The re-evaluation of new and regenerated nitrogen uptake as well as the $f$ ratio indicate that regenerative nitrogen fluxes are more important in the NE Atlantic Ocean than previously thought, and can support 10 to $100 \%$ of nitrate demand and up to $30 \%$ of ammonium uptake.

One of the most striking characteristics of the POMME study area was the persistence of favourable regeneration conditions during the year. Hydrological 
conditions included deep mixing (up to $200 \mathrm{~m}$ ) even in spring, combined with deep light penetration (down to $70 \mathrm{~m}$ during winter, Fernández I. et al. 2005b). In such conditions, light limitation of phytoplankton does not seem to affect new production; furthermore, it does not appear to have a clear effect on nitrification. During winter, the persistence of a nitrite maximum at the base of the euphotic zone seems highly modulated by physics, as opposed to spring (up to $0.6 \mu \mathrm{M}$ ) when it became a clear feature in our profiles (Fig. 2). However, the lack of a $\mathrm{NO}_{2}^{-}$maximum during winter should not be associated with the absence of processes such as ammonium oxidation $\left(\mathrm{NO}_{2}{ }^{-}\right.$is an intermediate product of nitrification). This biogeochemical feature, widely distributed in the ocean (Vaccaro \& Ryther 1960, Olson 1981, Dore \& Karl 1996), has often been considered an indicator of new production through phytoplankton excretion, or bacterial oxidation of organic matter, as well as a signature of the depth at which light-limitation occurs (Dore \& Karl 1996, Ward et al. 1989). Although our values are lower than previously described for stratified and oceanic areas (Hisard \& Piton 1969, Hattori \& Wada 1971), they are higher than previous reports for the Atlantic (Zafiriou et al. 1992, Lipschultz et al. 1996). The maintenance of a nitrite maximum during our study confirms the existence of intense regeneration activity, even during the most productive season of the year (spring primary production: $1.24 \mathrm{~g} \mathrm{~m}^{-2} \mathrm{~d}^{-1}$, Fernández I. et al. 2005a).

While ammonium concentrations in the upper water column are controlled by numerous fluxes of production and consumption, they can also be considered as an indicator of organic matter mineralization (Bianchi et al. 1997). Ammonium levels during this study were high (up to $0.2 \mu \mathrm{M}$ during winter and $0.46 \mu \mathrm{M}$ during spring), but stayed in the range of previous studies in the NE Atlantic (e.g. Woodward \& Rees 2001), suggesting intense $\mathrm{NH}_{4}^{+}$recycling in the euphotic zone.

Previous studies (Woodward \& Rees 2001, Martin \& Pondaven 2003) have focussed on the role of mesoscale activity (mainly through 'eddy pumping') in the transport of nutrients - both regenerated and new - to the euphotic zone. However, their effect as 'new production enhancers' is still under debate. Mesoscale features are well documented for the POMME study area (see Mémery et al. 2005), especially for second legs of all cruises. Nevertheless, in spite of being clearly associated with high nutrient concentrations compared with surrounding waters (Fernández I. et al. 2005b), and although they showed high N-regeneration rates, their role in enhancing $\mathrm{C}$ or $\mathrm{N}$ cycling is not clear. Further studies are required to clarify this aspect.

\section{Nitrification and new primary production}

Although the potential significance of 'regenerated' nitrate in the euphotic zone has been acknowledged for some time (Dugdale \& Goering 1967, Ward et al. 1989, Dore \& Karl 1996, Bianchi et al. 1997, Diaz \& Raimbault 2000, Ward 2000), there is still little information regarding the inhibitory effect of light on nitrification in marine environments (Ward 1985, Horrigan \& Springer 1990), and even less concerning its quantification on an annual or seasonal basis. While nitrification studies have been performed in a variety of marine environments (Ward et al. 1984, Codispoti \& Christensen 1985, Ward \& Zafiriou 1988), observations in the open ocean are rare. Whether because of the difficulty of measuring in situ rates or its presumed small contribution to total $\mathrm{NO}_{3}{ }^{-}$assimilation, nitrification measurements in the field are far from being routinely measured in oceanographic cruises.

Nitrification rates presented here are in the range of previous observations (e.g. Ward \& Zafiriou 1988, Bianchi et al. 1994, Ward 2005), but proved to be significant even during the spring bloom, which was followed by local phytoplankton blooms until May 2001 (Leblanc et al. 2005). Nitrification was intense in the entire water column and was largely able to sustain plankton DIN demand. Furthermore, total ambient ammonium recycling within $24 \mathrm{~h}$ was possible during both seasons. Nitrification in surface waters was as high as in deeper layers, suggesting limitation of photoautotrophic predominance in surface waters by competition between phytoplankton and bacteria (often induced by pelagic nitrification). The presence of a subsurface nitrification maximum at the base of the euphotic zone during spring can be related (among other factors) to increased stratification, active remineralization of sinking organic matter and grazing. Seasonally, about $40 \%$ of nitrate uptake in the top $80 \mathrm{~m}$ was supported by nitrification during winter, and $20 \%$ during spring. Locally, nitrification could support 4 to $100 \%$ of local surface nitrate assimilation (e.g. Stn 173). Previous studies (Priscu \& Downes 1985, Ward 1987, Ward et al. 1989, Dore \& Karl 1996, Raimbault et al. 1999) came to similar conclusions. In the equatorial Pacific, 20 to $100 \%$ of total nitrate demand could be fulfilled by nitrification in the euphotic zone, and even $142 \%$ at the Hawaii Ocean Time-Series station ALOHA (Dore \& Karl 1996). Our results confirm these observations and suggest a widely significant role of nitrification in the upper layers of oceanic areas. A logical conclusion is the possibility of considerable overestimations in current new production estimates that do not take $\mathrm{N}$ regeneration into account. For the NE Atlantic, such overestimations of new production (in the sense of Dugdale \& Goering 1967) could reach $10 \%$ on an annual basis and up to $100 \%$ at daily rates. 
Interestingly, recent experiments observed active $\mathrm{NO}_{3}{ }^{-}$uptake by heterotrophic bacteria, reaching 16 to $40 \%$ of $\mathrm{NO}_{3}{ }^{-}$assimilation (Allen et al. 2002). Implications for areas of intense $\mathrm{NO}_{3}{ }^{-}$cycling could include further overestimations of autotrophic uptake and new primary production, because bacteria can become not only producers but consumers of regenerated (and new) nitrate.

\section{$\mathrm{NH}_{4}{ }^{+}$cycling: contribution of small cells}

There are seldom measurements of ammonium regeneration in oceanic waters in the literature, but our results are in the range of the scarce available data (e.g. Bode et al. 2002). Rates of $\mathrm{rNH}_{4}$ were high in surface waters during winter $\left(0.172 \mu \mathrm{M} \mathrm{d}^{-1}\right)$ and spring $\left(0.423 \mu \mathrm{M} \mathrm{d}^{-1}\right)$.

Being a preferred source of nitrogen for marine phytoplankton and bacteria, ammonium is also a substrate of competition for autotrophic and heterotrophic organisms of small size. The effect of $\mathrm{rNH}_{4}$ on ammonium uptake rates (and subsequently for regenerated production) was high during winter and spring ( 40\%) and was particularly important in the top $50 \mathrm{~m}$ of the water column. Similar results were described for the open Atlantic Ocean, where 12 to $40 \%$ of total $\mathrm{NH}_{4}{ }^{+}$ uptake was related to bacteria (Allen et al. 2002). Other $\mathrm{N}$ forms such as urea are actively assimilated and can have a significant effect on regenerated production (Allen et al. 2002). Although urea was reported as a source of $\mathrm{N}$ for phytoplankton and only few reports of heterotrophic uptake of urea exist (Kirchman 2000), a more accurate quantification of N cycling should include these fluxes, despite the difficulties of the methods involved.

It is worth making a brief comment concerning $\mathrm{NH}_{4}{ }^{+}$ cycling during P2L2. Early in spring (P2L1), $\mathrm{rNH}_{4}$ and $\rho_{\text {DIN }}^{\text {loss }}$ seemed to be directly related $\left(\mathrm{rNH}_{4}=0.8295\right.$ DON loss $+31.85, \mathrm{R}^{2}=0.65$; data not shown), which suggests active grazing pressure for both processes because DON is a suitable substrate for bacteria and can also be excreted by zooplankton and unicellular plankton. However, the high rates of $\rho_{\text {DIN }}^{\text {loss }}$ obtained later in the season (P2L2) were probably due to high $\mathrm{NH}_{4}{ }^{+}$uptake in the $<0.7 \mu \mathrm{m}$ size fraction and possibly to heterotrophic assimilation of recently released DON labelled as ${ }^{15} \mathrm{~N}$. Filtration through $0.2 \mu \mathrm{m}$ ensured real $\rho_{\text {DIN }}^{\text {loss }}$ estimations, revealing a much lower proportion of DIN going to the dissolved organic compartment $(<14 \%)$. $\mathrm{NH}_{4}{ }^{+}$uptake in the $<0.7 \mu \mathrm{m}$ fraction (which includes bacteria, Bronk \& Glibert 1994, Synechoccocus sp. and prochlorophytes, Altabet 1990) contributed to $30 \%$ of ammonium uptake. The origin of this problem lies in a methodological constraint. The efficiency of glass fiber filters (mainly Whatman GF/F) has been repeatedly verified in marine environments (e.g. Altabet 1990, Raimbault et al. 1999, Diaz \& Raimbault 2000, Saldanha-Corrêa et al. 2004). Comparisons of different types of filters, including $0.2 \mu \mathrm{m}$ Anopore aluminium oxide membranes (Altabet 1990, Slawyk \& Raimbault 1995), indicated that a significant fraction of the particulate nitrogen collected by $0.2 \mu \mathrm{m}$ Anopore membranes could pass through GF/F filters, and the relative importance of the fraction that was neglected increased with depth. However, since nitrate and ammonium assimilation occurs mainly in surface waters, it was suggested that integrated uptake rates would not be significantly underestimated in the $>0.7 \mu \mathrm{m}$ fraction. During late spring, the use of GF/F filters led to underestimations of ammonium uptake and a failure to estimate the released DON. We suggest that, for some particular cases in open ocean environments, the role of particles smaller than $0.7 \mu \mathrm{m}$ in ammonium assimilation can exceed the performance of larger phytoplanktonic cells. In such conditions, the use of Anopore aluminium oxide $0.2 \mu \mathrm{m}$ membranes should not be avoided, but the problem persists due to their low filtration speed, high cost and potential incompatibility with mass spectrometry analysis. In spite of the existence of 2 alternative glass fiber filters (AP-40 Millipore and GF-5 Macherey Nagel) with approximate nominal porosities ( 0.45 and $0.4 \mu \mathrm{m}$ respectively), their retention performance is compromised in oligotrophic conditions (Saldanha-Corrêa et al. 2004). New technology is needed to ensure routine filtration and analysis of the smallest fraction of marine ultraplankton.

In terms of export production, the underestimation of total ammonium uptake rates by filtration through GF/F filters should not have consequences for $f$ (Eppley \& Peterson 1979). This is because ammonium uptake in the $<\mathrm{GF} / \mathrm{F}$ size fraction is performed almost entirely by bacteria and it cannot be included in the estimation of regenerated production, which is associated with autotrophic fixation of carbon. The $f$ ratio only provides an indirect estimation of particulate organic matter export to the deep ocean if suitable time scales are considered. This concept assumes a balance between the input of nitrate by advection and the losses from the surface to the deep. However, our observations showed rates of regeneration of nitrogenous nutrients $\left(\mathrm{NH}_{4}{ }^{+}\right.$regeneration and nitrification) in the euphotic zone that could supply up to $100 \%$ of local nutrient assimilation. This raises the question of the validity of estimating $f$ through ${ }^{15} \mathrm{~N}$ tracer methods, because in situ nitrogen recycling seems to be widely important. In order to improve calculations of the $f$ ratio in nitrogen and carbon budgets at a global and regional scale, nitrogen regeneration fluxes need to be properly and systematically quantified. 
Acknowledgements. This study was part of the POMME project, which was funded by PATOM/PROOF (France) and headed by L. Mémery and G. Reverdin. We thank N. Garcia, P. Rimmelin and B. Boudjellal for valuable help during sampling and laboratory analysis. The captain and crew of RV 'L'Atalante' provided excellent assistance during both cruises. H. Claustre provided euphotic layer depth data. Four anonymous referees are acknowledged for constructive comments that greatly improved the manuscript.

\section{LITERATURE CITED}

Allen CB, Kanda J, Laws EA (1996) New production and photosynthetic rates within and outside a cyclonic mesoscale eddy in North Pacific subtropical gyre. Deep-Sea Res II 43:917-936

Allen AE, Howard-Jones MH, Booth MG, Frisher ME, Verity PG, Bronk DA, Sanderson MP (2002) Importance of heterotrophic bacterial assimilation of ammonium and nitrate in the Barents Sea during summer. J Mar Syst 38:93-108

Altabet M (1990) Organic C, N and stable isotopic composition of particulate matter collected on glass-fiber and aluminium oxide filters. Limnol Oceanogr 35:902-909

Bianchi M, Bonin P, Feliatra F (1994) Bacterial nitrification and denitrification rates in the Rhône River plume (northwestern Mediterranean Sea). Mar Ecol Prog Ser 103:197-202

Bianchi M, Feliatra F, Tréguer P, Vincendeau M, Morvan J (1997) Nitrification rates, ammonium and nitrate distribution in upper layers of the water column and in sediments of the Indian sector of the Southern Ocean. Deep-Sea Res II 44:1017-1032

Bode A, Castro C, Doval MD, Varela M (2002) New and regenerated production and ammonium regeneration in the western Bransfield region (Antarctica) during phytoplankton bloom conditions in summer. Deep-Sea Res II 49: 787-804

Bronk DA, Glibert P, Ward BB (1994) Nitrogen uptake, dissolved organic nitrogen release and new production. Science 256:1843-1846

Codispoti LA, Christensen JP (1985) Nitrification, denitrification and nitrous oxide cycling in the eastern tropical South Pacific Ocean. Mar Chem 16:277-300

Diaz F, Raimbault P (2000) Nitrogen regeneration and dissolved organic nitrogen release during spring in a NW Mediterranean coastal zone (Gulf of Lions): implications for the estimation of new production. Mar Ecol Prog Ser 197:51-65

Dore JE, Karl DM (1996) Nitrification in the euphotic zone as a source for nitrite, nitrate, and nitrous oxide at station ALOHA. Limnol Oceanogr 41:1619-1628

Dugdale RC, Goering JJ (1967) Uptake of new and regenerated forms of nitrogen in primary productivity. Limnol Oceanogr 12:196-206

Dugdale RC, Wilkerson FP (1986) The use of ${ }^{15} \mathrm{~N}$ to measure nitrogen uptake in eutrophic oceans, experimental considerations. Limnol Oceanogr 31:673-689

Eppley RW, Peterson BJ (1979) Particulate organic matter flux and planktonic new production in the deep ocean. Nature 282:677-680

Eppley RW, Renger EH (1992) Nitrate utilization by plankton in the equatorial pacific march 1988 along $150^{\circ} \mathrm{W}$. J Geophys Res 97:663-668

Fernández I. C, Raimbault P, Garcia N, Rimmelin P, Claustre H, Ras J, Caniaux G (2005a) An estimation of annual new production and carbon budgets in the northeast
Atlantic Ocean during 2001. J Geophys Res 110:C07S13, doi:10.1029/2004JC002616

Fernández I. C, Raimbault P, Caniaux G, Garcia N, Rimmelin $P(2005 b)$ Impact of mesoscale features on seasonal distribution of nitrate in the Northeast Atlantic Ocean. J Mar Syst 55:155-175

Gentilhomme V, Raimbault P (1994) Absorption et régénération de l'azote dans la zone frontale du courant Algérien (Méditerranée Occidentale): réévaluation de la production nouvelle. Oceanol Acta 17:555-562

Glibert PM, Lipschultz F, McCarthy JJ, Altabet MA (1982) Isotope dilution models of uptake and remineralization of ammonium by marine plankton. Limnol Oceanogr 27: $639-650$

Harrison WG, Douglas D, Falkowski P, Rowe G, Vidal J (1983) Summer nutrient dynamics of the middle Atlantic Bight: nitrogen uptake and regeneration. J Plankton Res 5: 539-556

Hattori A, Wada E (1971) Nitrite distribution and its regulating processes in the equatorial Pacific Ocean. Deep-Sea Res 18:557-568

Hisard PH, Piton B (1969) La distribution du nitrite dans le système des courants équatoriaux de l'Océan Pacifique, à $170^{\circ} \mathrm{E}$. J Cons Int Explor Mer 32:303-317

Horrigan S, Springer AL (1990) Oceanic and estuarine ammonium oxidation-effects of light. Limnol Oceanogr 35: $479-482$

Kirchman DL (2000) Uptake and regeneration of inorganic nutrients by marine heterotrophic bacteria. In: Kirchman DL (ed) Microbial ecology of the oceans. Wiley-Liss, New York, p 261-288

Laws E (1984) Isotope dilution models and the mystery of the vanishing ${ }^{15} \mathrm{~N}$. Limnol Oceanogr 29:379-386

Leblanc K, Leynaert A, Fernández I. C, Rimmelin P, Moutin T, Raimbault P, Ras J, Queguiner B (2005) A seasonal study of diatom dynamics in the North Atlantic during the POMME experiment (2001): evidence of Si limitation of the spring bloom. J Geophys Res 110:C07S14, doi: 10.1029/2004JC002621

Lipschultz F, Zafiriou OC, Ball LA (1996) Seasonal fluctuations of nitrite concentrations in the deep oligotrophic ocean. Deep-Sea Res II 43:403-419

Martin A, Pondaven P (2003) On the estimates for vertical nitrate flux due to eddy pumping. J Geophys Res 108: 3359, doi:10.1029/2003JC001841

Mémery L, Reverdin G, Paillet J, Oschlies A (2005) Introduction to the POMME special section: thermocline ventilation and biogeochemical tracer distribution in the northeast Atlantic Ocean and impact of mesoscale dynamics. J Geophys Res 110:C07S01, doi:10.1029/2005JC 002976

Morel A, Maritorena S (2001) Bio-optical properties of oceanic waters: a reappraisal. J Geophys Res 106:7163-7180

Olson RJ (1981) Differential photoinhibition of marine nitrifying bacteria: a possible mechanism for the formation of the primary nitrite maximum. J Mar Res 39:227-238

Priscu JC, Downes MT (1985) Nitrogen uptake, ammonium oxidation and nitrous oxide $\left(\mathrm{N}_{2} \mathrm{O}\right)$ levels in the coastal waters of western Cook Strait, New Zealand. Estuar Coast Shelf Sci 20:529-542

Raimbault P, Slawyk G, Boudjellal B, Coatanoan C and 5 others (1999) Carbon and nitrogen uptake and export in the equatorial pacific at $150^{\circ} \mathrm{W}$ : evidence of an efficient regenerated production cycle. J Geophys Res 104: 3341-3356

Saldanha-Corrêa F, Gianesella SM, Barrera-Alba JJ (2004) A comparison of the retention capability of three different 
glass-fiber filters used for chlorophyll-a determinations. Bras J Oceanogr 52:243-247

Slawyk G, Raimbault P (1995) Simple procedure for the simultaneous recovery of dissolved inorganic and organic nitrogen in ${ }^{15} \mathrm{~N}$-tracer experiments and improving the isotopic mass balance. Mar Ecol Prog Ser 124:289-299

Slawyk G, Raimbault P, Garcia, N (1998) Measuring gross uptake of ${ }^{15} \mathrm{~N}$ labelled nitrogen by marine phytoplankton without particulate matter collection: evidence of low ${ }^{15} \mathrm{~N}$ losses to the dissolved organic nitrogen pool. Limnol Oceanogr 43:1734-1739

Slawyk G, Raimbault P, Garcia N (2000) Use of ${ }^{15} \mathrm{~N}$ to measure dissolved organic nitrogen release by marine phytoplankton (reply to comment by Bronk and Ward). Limnol Oceanogr 45:1884-1886

Takahashi T, Sutherland SC, Sweeney C, Poisson A and 8 others (2002) Global sea-air $\mathrm{CO}_{2}$ flux based on climatological surface ocean $\mathrm{pCO}_{2}$, and seasonal biological and temperature effects. Deep-Sea Res II 49:1601-1622

Tréguer P, LeCorre P (1975) Manuel d'analyses des sels nutritifs dans l'eau de mer: utilisation de l'Autoanalyser II Technicon, 2nd edn. Université de Bretagne Occidentale, Brest

Vaccaro RF, Ryther J (1960) Marine phytoplankton and the distribution of nitrite in the sea. J Const Int Explor Mer 25: $260-271$

Editorial responsibility: Otto Kinne (Editor-in-Chief), Oldendorf/Luhe, Germany
Ward BB (1985) Light and substrate concentrations relationships with marine ammonium assimilation and oxidation rates. Mar Chem 16:301-316

Ward BB (1987) Nitrogen transformations in the Southern California Bight. Deep-Sea Res 34:785-805

Ward BB (2000) Nitrification and the marine nitrogen cycle. In: Kirchman DL (ed) Microbial ecology of the oceans. Wiley-Liss, New York, p 427-454

Ward BB (2005) Temporal variability in nitrification rates and related biogeochemical factors in Monterey Bay, California, USA. Mar Ecol Prog Ser 292:97-109

Ward BB, Zafiriou OC (1988) Nitrification and nitric oxide in the oxygen minimum of the eastern tropical North Pacific. Deep-Sea Res 35:1127-1142

Ward BB, Talbot MC, Perry MJ (1984) Contributions of phytoplankton and nitrifying bacteria to ammonium and nitrite dynamics in coastal waters. Cont Shelf Res 3:383-398

Ward BB, Kilpatrick KA, Renger EH, Eppley RW (1989) Biological nitrogen cycling in the nitracline. Limnol Oceanogr 34:493-513

Woodward EMS, Rees AP (2001) Nutrient distributions in an anticyclonic eddy in the northeast Atlantic Ocean, with reference to nanomolar ammonium concentrations. DeepSea Res II 48:775-794

Zafiriou OC, Ball LA, Hanley Q (1992) Trace nitrite in oxic waters. Deep-Sea Res 39:1329-1348

Submitted: June 16, 2006; Accepted: September 29, 2006 Proofs received from author(s): April 23, 2007 